\title{
SUBSTITUSI TEPUNG BONGGOL PISANG PADA MIE BASAH DENGAN PENAMBAHAN KULIT BUAH NAGA (Hylocereus undatus)
}

\section{Substitution Of Banana Tuber Flour Into Wet Noodles With The Addition Of Dragon Fruit (Hylocereus undatus) Skin}

\author{
Gede Sumardana 1), Husain Syam 2), Andi Sukainah 3). \\ 1)Mahasiswa Program Studi Pendidikan Teknologi Pertanian FT UNM, \\ 2) dan ${ }^{3) D o s e n ~ F T ~ U N M ~}$ \\ sumardana.gen@gmail.com
}

\begin{abstract}
ABSTRAK
Penelitian ini bertujuan untuk mengetahui pengaruh substitusi tepung umbi pisang dan penambahan ekstrak kulit buah naga super merah terhadap kualitas mie basah. Penelitian ini terdiri dari dua tahap, langkah pertama adalah menemukan konsentrasi terbaik antara tepung terigu dan tepung pisang dalam pembuatan mie basah dan tahap kedua adalah penambahan ekstrak kulit buah naga super merah. Metode penelitian yang menggunakan rancangan acak lengkap (RAL), data penelitian diolah dengan teknik analisis sidik ragam ANOVA dengan uji lanjut DMRT (Duncan Multiple Rate). Hasil penelitian Tahap 1 menunjukkan bahwa substitusi tepung terigu dari tepung umbi pisang $285 \mathrm{~g}: 15 \mathrm{~g}$ merupakan perlakuan terbaik dengan karakteristik hedonik untuk rasa 3,57, warna 3,69, aroma 3,43, dan tekstur 3,61. penelitian tahap 2 menunjukkan bahwa mie basah tanpa penambahan ekstrak kulit buah naga super merah adalah perlakuan terbaik dengan karakteristik hedonik untuk rasa 3,53, warna 3,21, aroma 3,31 dan tekstur 3,41 dan kadar air 58,14\%, kadar abu 0,72\%, 0,48\% kadar serat, dan kadar antioksidan $1,01 \%$.

Kata Kunci : Tepung Bonggol Pisang, kulit buah naga super merah, dan Mie basah
\end{abstract}

\section{ABSTRACT}

This study aims to determine the effect of substitution of banana tuber flour and the addition of super red dragon fruit skin extract to the quality of wet noodles. This study consists of two stages, the first step is to find the best concentration between wheat flour and banana tuber flour in the making of wet noodles and the second stage is the addition of super red dragon fruit skin extract. The research method used is complete randomized design (RAL), the research data is processed by ANOVA variance analysis technique with further test of DMRT (Duncan Multiple Rate). The results of the Phase 1 study showed that the substitution of wheat flour from banana tuber flour $285 \mathrm{~g}: 15 \mathrm{~g}$ was the best treatment with hedonic characteristics for flavor 3,57, color 3,69, aroma 3,43, and texture 3, 61. Phase 2 research showed that the wet noodle without the addition of red dragon fruit skin extract is the best treatment with hedonic characteristic for taste of 3,53, color 3,21, flavour 3,31 and texture 3,41 with water content $58,14 \%$, ash $0,72 \%, 0.48 \%$ fiber content, and antioxidant levels of 1.01 .

Keywords: Banana Tuber Flour, Super Red Dragon Fruit Skin, And Wet Noodle 


\section{PENDAHULUAN}

Peningkatkan nilai ekonomi bahan pangan lokal, dapat dilakukan dengan melakukan diversifikasi pangan ditingkat nasional dan regional. Diversifikasi dilakukan untuk mengurangi ketergantungan terhadap beras dan terigu sebagai sumber pangan karbohidrat. Beberapa sumber karbohidrat yang dapat digunakan yaitu umbi-umbian, pisang, sagu, kacangkacangan, serealia, dan lain- lain. Pangan lokal tersebut memiliki karakteristik fisik dan kimia yang berbeda- beda, yang menentukan jenis pengolahan selanjutnya untuk mendapatkan produk pangan yang berkualitas. (Lensun, 2013).

Salah satu tanaman yang menghasilkan umbi (bonggol) adalah pisang, Bonggol pisang (umbi batang pisang) merupakan bahan makanan yang jarang dimanfaatkan oleh masyarakat, bahkan mungkin belum dimanfaatkan sama sekali, dan dapat dijadikan sebagai bahan diversifikasi pangan. Kebanyakan bagian bonggol tersebut tidak terpakai dan dibuang. Dalam kemajuannya, terdapat beberapa produk Yang dapat diolah dari bonggol pisang antara lain keripik bonggol pisang, sayur lodeh bonggol pisang, cuka bonggol pisang, dan tepung bonggol pisang.

Pemanfaatan bonggol pisang menjadi tepung didasarkan bahwa bonggol pisang mengandung karbohidrat yang cukup tinggi sehingga dapat diolah menjadi sumber tepung baru. Menurut Rosdiana (2009), bonggol pisang memiliki komposisi yang terdiri dari $76 \%$ pati dan $20 \%$ air.

Salah satu pengolahan tepung bonggol pisang adalah pengolahan menjadi mie, masyarakat dewasa ini banyak mengkonsumsi mie sebagai bahan pangan alternative pengganti nasi. Dikarenakan sifatnya yang praktis, rasa yang enak, harga terjangkau, dan penyajiannya mudah. mie dapat dikategorikan sebagai salah satu komoditi pangan substitusi karena dapat berfungsi sebagai bahan pangan pokok (Juniawati, 2003).

Kulit buah naga merupakan limbah hasil pertanian yang selama ini belum banyak dimanfaatkan, padahal kulit buah naga sendiri mengandung vitamin $C$, vitamin $E$, vitamin $A$, alkaloid, terpenoid, flavonoid, tiamin, niasin, piridoksin, kobalamin, fenolik, karoten, dan fitoalbumin (Jaafar,et al.,2009).

Selain itu kulit buah naga kaya polyphenol dan sumber antioksidan yang baik. Bahkan menurut studi yang dilakukannya terhadap total phenolik konten, aktivitas antioksidan dan kegiatan antiproliferative, kulit buah naga merah adalah lebih kuat inhibitor pertumbuhan sel-sel kanker dari pada dagingnya dan tidak mengandung toksik. (Li Chen Wu, et al., 2005)

Berdasarkan penjelasan mengenai latar belakang yang telah dijelaskan sebelumnya, maka dilakukan penelitian pengolahan mie basah dengan menggunakan tepung bonggol pisang sebagai bahan substitusi dan penambahan ekstrak kulit buah naga

\section{TUJUAN PENELITIAN}

Penelitian ini bertujuan untuk mengetahui pengaruh substitusi tepung bonggol pisang terhadap mutu mie basah dan pengaruh penambahan ekstrak kulit buah naga terhadap kualitas mie basah. 


\section{METODE PENELITIAN}

Jenis penelitian ini adalah penelitian eksperimen (experiment research). Penelitian ini terdiri dari 2 tahap, tahap I yaitu mencari konsentrasi substitusi tepung terigu dan tepung bonggol pisang terbaik dan tahap II yaitu penambahan ekstrak kulit buah naga pada substitusi mie basah terbaik. Desain penelitian tahap I menggunakan model Rancangan Acak Lengkap (Randomized Completed Design) dengan 3 perlakuan dan 3 kali ulangan, sehingga jumlah unit percobaan yang akan diperoleh sebanyak 9 unit. Desain penelitian tahap II menggunakan model Rancangan Acak Lengkap (Randomized Completed Design) dengan 4 perlakuan dan 3 kali ulangan, sehingga jumlah unit percobaan yang akan diperoleh sebanyak 12 unit.

Peralatan yang digunakan dalam penelitian ini yaitu; baskom, pisau, talenan, baskom, kompor gas, timbangan digital, spatula, panci, gelas ukur, mesin pencetak mie, wadah plastik ukuran sedang, dan. Bahan yang digunakan yaitu; bonggol pisang kapok, kulit buah naga, tepung terigu, tepung bonggol pisang, telur, air, minyak goring, soda abu, cmc, dan garam, minyak goreng, air, dan gas elpiji.

Alur proses pembuatan mie basah pada penelitian tahap I yaitu; pembuatan tepung bonggol pisang dimulai dengan pengupasan bonggol pisang. Setelah itu, bonggol pisang dicuci dan di iris tipis dengan ketebalan $2-3 \mathrm{~mm}$. Kemudian direndam kedalam larutan metabisulfit 100 ppm selama 15 menit. Kemudian ditiriskan lalu dijemur di bawah sinar matahari sampai mencapai kadar air 10 - $12 \%$. Kemudian di tumbuk dengan lesung dan dilakukan pengayakan 60 mesh.
Pembuatan mie basah dengan substitusi tepung bonggol pisang dimulai dengan pencampuran tepung terigu dan tepung bonggol pisang dengan konsentrasi sebagai berikut:

1. $285 \mathrm{~g}$ tepung terigu : $15 \mathrm{~g}$ tepung bonggol pisang (perlakuan $\mathrm{A}$ )

2. $270 \mathrm{~g}$ tepung terigu : $30 \mathrm{~g}$ tepung terigu (perlakuan B)

3. $255 \mathrm{~g}$ tepung terigu : $45 \mathrm{~g}$ tepung bonggol pisang (perlakuan $\mathrm{C}$ )

Kemudian ditambahkan garam, telur, soda abu, cmc, dan air. kemudian dilakukan pengulenan adonan selama 20 menit. Setelah itu dilakukan pembentukan lembaran mie sampai terbentuk lembaran tipis. Setelah itu, lembar dicetak dengan alat pencetak mie.

Kemudian mie direbus selama 2 menit, angkat kemudian tiriskan. Alur proses pembuatan mie basah pada penelitian tahap II yaitu; Pembuatan ekstrak kulit buah naga super merah dimulai dengan mengupas buah naga untuk diambil kulitnya. Kemudian kulitnya dicuci bersih dan dipotong dadu. Kemudian ditimbang sebanyak $100 \mathrm{~g}$ dan direbus dengan air $100 \mathrm{ml}$ pada suhu $75-80^{\circ} \mathrm{C}$ selama 15 menit. Kemudian didiamkan selama 30 menit lalu disaring dengan kain kasa.

Mie basah dengan substitusi tepung terigu dan tepung bonggol pisang terbaik dibuat ulang dan dilakukan penambahan ekstrak kulit buah naga dengan perlakuan sebai berikut :

1. Tanpa penambahan ekstrak kulit buah naga (perlakuan $\mathrm{K}$ )

2. Penambahan ekstrak kulit buah naga $100 \mathrm{ml}$ (perlakuan X)

3. Penambahan ekstrak kulit buah naga $120 \mathrm{ml}$ (perlakuan Y)

4. Penambahan ekstrak kulit buah naga $140 \mathrm{ml}$ (perlakuan Z) 
Penelitian ini akan dilaksanakan di Laboratorium Pendidikan Teknologi Pertanian, Fakultas Teknik Universitas Negeri Makassar untuk pembuatan mie basah dan uji organoleptik seperti: tekstur, warna, rasa dan aroma. Laboratorium kimia Kimia Makanan Ternak, Jurusan Nutrisi dan Makanan Ternak, Fakultas Peternakan Universitas Hasanuddin untuk uji kimia seperti: kadar air, kadar abu, kadar serat, dan antioksidan. Waktu penelitian mulai dari persiapan sampai dengan pengamatan, membutuhkan waktu kurang lebih satu minggu, dimulai Pada Tanggal 09 februari sampai 16 Februari 2017. Pengumpulan data penelitian tahap I dilakuakn dengan uji organoleptik (warna, aroma, rasa, dan tekstur ).

Pengumpulan data penelitian tahap II dilakuan dengan uji organoleptik (warna, aroma, rasa, dan tekstur ) dan uji kimia yang meliputi : kadar air, kadar abu, kadar serat dan antioksidan. Data hasil analisis pada penelitian ini diuji secara statistik menggunakan sidik ragam ANOVA dengan SPSS. Jika terdapat perbedaan maka dilanjutkan dengan Duncan Mulitiple Range Test (DMRT) pada $a=0,05$.

\section{HASIL DAN PEMBAHASAN}

\section{Penelitian Tahap I}

\section{Rasa}

Berdasarkan data yang telah diperoleh, maka dapat diketahui bahwa untuk kategori rasa mie basah perlakuana $A$ dengan substitusi tepung terigu dan tepung bonggol pisang yaitu $285 \mathrm{~g}: 15 \mathrm{~g}$ adalah perlakuan yang paling disukai oleh panelis. Tingkat kesukaan panelis terhadap rasa mie basah dapat dilihat pada Gambar 1.

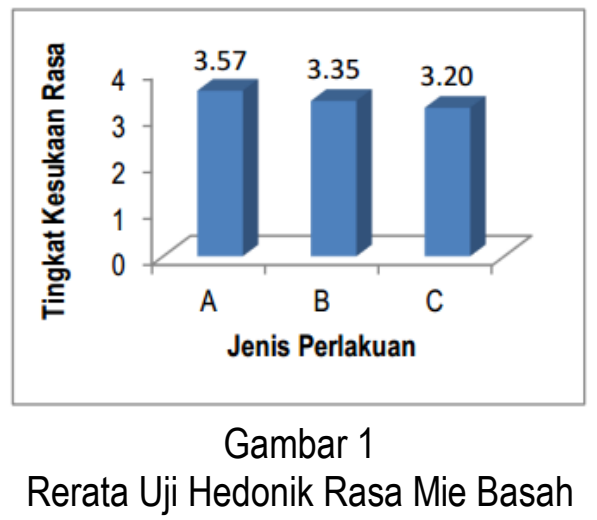

Ket :

$\mathrm{A}=$ Tepung terigu $185 \mathrm{~g}$ : tepung bonggol pisang $15 \mathrm{~g}$

$\mathrm{B}=$ =Tepung terigu $170 \mathrm{~g}$ : tepung bonggol pisang $30 \mathrm{~g}$

$\mathrm{C}=$ =Tepung terigu $155 \mathrm{~g}$ : tepung bonggol pisang $45 \mathrm{~g}$

Hasil analisis sidik ragam terhadap rasa mie basah menunjukkan bahwa substitusi tepung bonggol pisang memberikan pengaruh yang nyata terhadap rasa mie basah yang di hasilkan. Berdasarkan hasil uji lanjut Duncan, rasa terbaik diperoleh pada perlakuan A yaitu substitusi tepung terigu dan tepung bonggol pisang $285 \mathrm{~g}$ : $15 \mathrm{~g}$. Rasa mie basah yang dihasilkan dari konsentrasi tepung bonggol pisang yang berbeda yaitu semakin banyak penambahan tepung bonggol pisang maka tingkat kesukaan panelis terhadap rasa mie basah akan menurun. Hal ini disebabkan karena dalam bonggol pisang terdapat getah yang mengandung saponin yang dapat mempengaruhi rasa sepat atau pahit pada tepung bonggol pisang yangdihasilkan untuk diolah menjadi mie basah dan tidak toksik apabila di konsumsi oleh manusia. Selain itu getah dari bonggol pisang juga mengandung tannin yang dapat menimbulkan rasa ketir dilidah karena bereaksi dengan protein mukosa di mulut sehingga kurang disukai panelis (Estiasih dan Ahmadi, 2011). 
Warna

Berdasarkan data yang telah diperoleh, tingkat kesukaan panelis terhadap warna mie basah dapat dilihat pada Gambar 2.

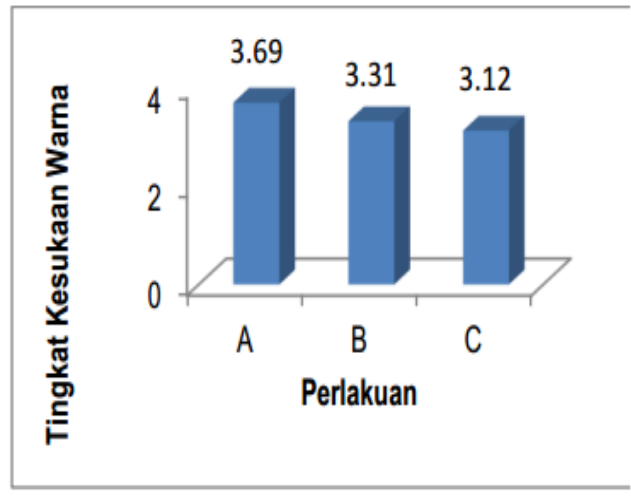

Gambar 2.

Rerata Uji Hedonik Warna Mie Basah

Ket :

$\begin{aligned} \mathrm{A}= & \text { Tepung terigu } 185 \mathrm{~g}: \text { tepung } \\ & \text { bonggol pisang } 15 \mathrm{~g} \\ \mathrm{~B}= & \text { Tepung terigu } 170 \mathrm{~g}: \text { tepung } \\ & \text { bonggol pisang } 30 \mathrm{~g} \\ \mathrm{C}= & \text { Tepung terigu } 155 \mathrm{~g}: \text { tepung } \\ & \text { bonggol pisang } 45 \mathrm{~g}\end{aligned}$

Hasil analisis sidik ragam terhadap warna mie basah menunjukkan bahwa substitusi tepung bonggol pisang memberikan pengaruh yang nyata terhadap warna mie basah yang di hasilkan. Berdasarkan hasil uji lanjut Duncan, warna terbaik diperoleh pada perlakuan $\mathrm{A}$ yaitu substitusi tepung terigu dan tepung bonggol pisang $285 \mathrm{~g}: 15 \mathrm{~g}$

Warna pada mie basah dengan substitusi tepung bonggol pisang memiliki warna kecokelatan. Semakin tinggi penambahan tepung bonggol pisang maka mie yang dihasilkan akan berwarna cokelat kegelapan. Hal ini disebabkan oleh Aktivitas enzim polyphenol oksidase (PPO) yang terkandung dalam umbi-umbian seperti bonggol pisang setelah pengupasan yang mengadakan kontak langsung dengan oksigen. Enzim polyphenol oksidase (PPO) menjadi O- hidroksi phenol yang selanjutnya diubah lagi menjadi O-kuinon inilah yang membentuk warna cokelat (Permatasari et al, 2009).

\section{Aroma}

Berdasarkan data yang telah diperoleh, tingkat kesukaan panelis terhadap aroma mie basah dapat dilihat pada Gambar 3.

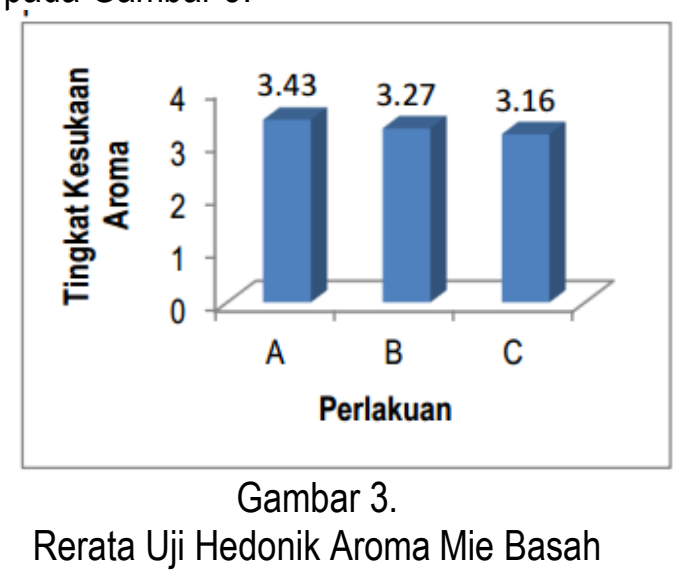

Ket :

$\mathrm{A}=$ Tepung terigu $185 \mathrm{~g}$ : tepung bonggol pisang $15 \mathrm{~g}$

$\mathrm{B}=$ Tepung terigu $170 \mathrm{~g}$ : tepung bonggol pisang $30 \mathrm{~g}$

$\mathrm{C}=$ Tepung terigu $155 \mathrm{~g}$ : tepung bonggol pisang $45 \mathrm{~g}$

Hasil analisis sidik ragam menunjukkan bahwa substitusi tepung bonggol pisang tidak memberikan pengaruh yang nyata terhadap aroma mie basah yang di hasilkan. Aroma mie basah yang dihasilkan dengan substitusi tepung bonggol pisang sesuai perlakuan memiliki aroma khas getah pisang. Semakin tinggi konsentrasi penambahan tepung bonggol pisang maka aroma yang dihasilkan akan semakin meningkat. Hal tersebut dikarenakan mie basah dengan substitusi tepung bonggol pisang menghasilkan aroma yang khas 
yaitu terjadinya degradasi asam organik berupa ester dan volatil (Winarno, 2002).

\section{Tekstur}

Berdasarkan data yang telah diperoleh, tingkat kesukaan panelis terhadap tekstur mie basah dapat dilihat pada Gambar 4.

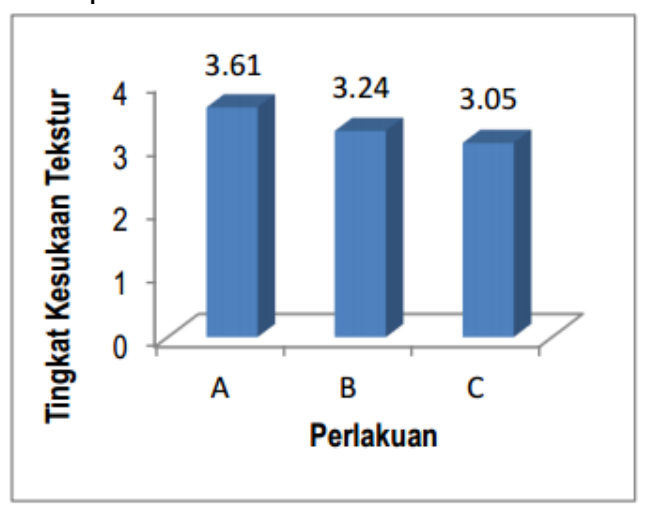

Gambar 4

Rerata Uji Hedonik Tekstur Mie Basah Ket :

$\mathrm{A}=$ Tepung terigu $185 \mathrm{~g}$ : tepung bonggol pisang $15 \mathrm{~g}$

$\mathrm{B}$ = Tepung terigu $170 \mathrm{~g}$ : tepung bonggol pisang $30 \mathrm{~g}$

$\mathrm{C}=$ Tepung terigu $155 \mathrm{~g}$ : tepung bonggol pisang $45 \mathrm{~g}$

Hasil analisis sidik ragam terhadap tekstur mie basah menunjukkan bahwa substitusi tepung bonggol pisang memberikan pengaruh yang nyata terhadap tekstur mie basah yang di hasilkan. Berdasarkan hasil uji lanjut Duncan, rasa terbaik diperoleh pada perlakuan A yaitu substitusi tepung terigu dan tepung bonggol pisang $285 \mathrm{~g}: 15 \mathrm{~g}$

Hal ini disebabkan karena tepung bonggol pisang mengandung protein yang rendah dan pati tepung bonggol pisang memiliki kandungan amilosa yang tinggi, amilosa memiliki viskositas dan kekentalan yang rendah sehingga tekstur mie basah yang dihasil kurang baik. Tekstur kenyal dan elastis pada mie basah disebabkan karena adanya zat gluten dan gluten tersebut terdapat pada tepung yang mengandung protein tinggi seperti tepung terigu. Zat gluten pada tepung terigu menyebabkan pengembangan adonan dan memungkinkan bertahannya carbon dioxide yang dihasilkan oleh busa yang beragi sehingga menimbulkan tekstur yang baik pada produk olahan (Sediaoetama, 2006).

\section{Penelitian Tahap II}

\section{Rasa}

Berdasarkan data yang telah diperoleh, tingkat kesukaan panelis terhadap rasa mie basah dengan penambahan ekstrak kulit buah naga super merah dapat dilihat pada Gambar 5.

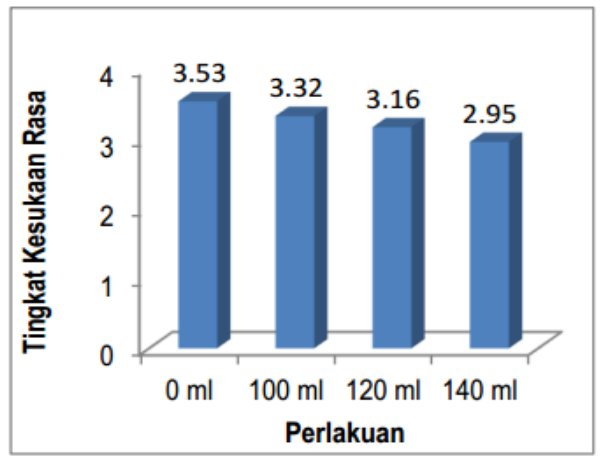

Gambar. 5

Rerata Uji Hedonik Rasa Mie Basah

Hasil analisis sidik ragam terhadap rasa mie basah menunjukkan bahwa perlakuan penambahan ekstrak kulit buah naga memberikan pengaruh yang nyata terhadap rasa mie basah yang di hasilkan. Berdasarkan hasil uji lanjut Duncan, rasa terbaik diperoleh pada perlakuan tanpa penambahan ekstrak kulit buah naga

Jika dilakukan penambahan ekstrak kulit buah naga super merah maka panelis menyukai perlakuan penambahan ekstrak kulit buah naga super merah $100 \mathrm{ml}$. Semakin tinggi konsentrasi ekstrak kulit buah naga 
super merah yang ditambahkan maka tingkat kesukaan panelis terhadap parameter rasa mie basah akan semakin menurun. Hal ini disebabkan karena adanya rasa pekat atau sepat dalam kulit buah naga yang sebanding dengan besarnya konsentrasi buah naga sehingga menurunkan kesukaan penelis terhadap parameter rasa mie basah. Hal ini sesuai dengan penelitian Ekawati et al, (2015) mengatakan bahwa semakin tinggi konsentrasi kulit buah naga maka semakin menurun kesukaan panelis terhadap rasa susu kedelai dan santan. Hal ini diduga karena kulit buah naga berkontribusi memberikan rasa pekat atau sepat sehingga tidak disukai panelis.

\section{Warna}

Berdasarkan data yang telah diperoleh, tingkat kesukaan panelis terhadap warna mie basah dengan penambahan ekstrak kulit buah nagasuper merah dapat dilihat pada Gambar 6.

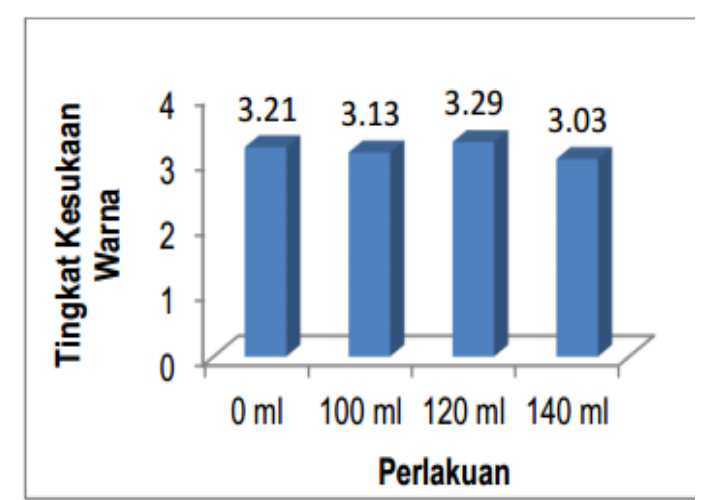

Gambar 6.

Rerata Uji Hedonik Warna Mie Basah

Hasil analisis sidik ragam

menunjukkan bahwa perlakuan penambahan ekstrak kulit buah naga super merah tidak memberikan pengaruh yang nyata terhadap warna mie basah yang dihasilkan.
Warna mie basah dengan atau tanpa penambahan ekstrak kulit buah naga super merah memiliki warna yang hampir sama atau sama sekali tidak berubah warnanya. Warna mie basah tetap berwarna agak kecokelatan, hal ini disebabkan karena adanya substitusi tepung bonggol pisang pada pembuatan mie basah sehingga warna dari ekstrak kulit buah naga super merah menjadi tidak nampak atau tenggelam. Hal ini disebabkan karena pigmen antosianin pada kulit buah naga terdegradasi oleh adanya oksigen dan oksidasi enzimatik, misalnya polifenol oksidase yang menghasilkan perubahan warna yang signifikan (Hidayah, 2013).

\section{Aroma}

Berdasarkan data yang telah diperoleh, tingkat kesukaan panelis terhadap aroma mie basah dengan penambahan ekstrak kulit buah naga super merah dapat dilihat pada Gambar 7.

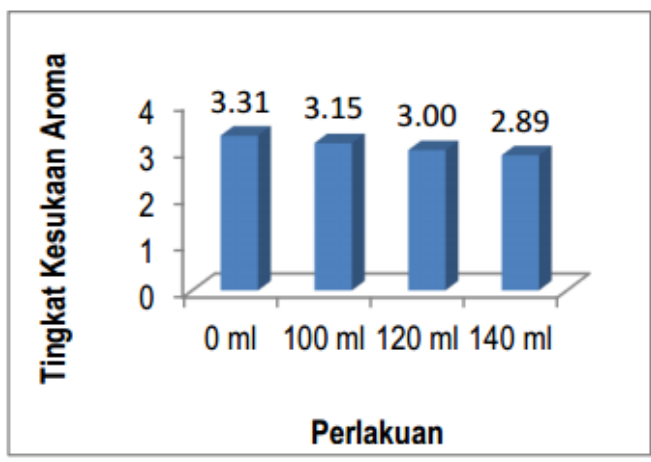

Gambar 7

Rerata Uji Hedonik Aroma

Hasil analisis sidik ragam menunjukkan bahwa perlakuan penambahan ekstrak kulit buah naga super merah memberikan pengaruh yang nyata terhadap aroma mie basah yang di hasilkan. Bersadarkan hasil uji lanjut Duncan, tekstur terbaik diperoleh pada perlakuan tanpa penambahan ekstrak kulit buah naga super merah. 
Penambahan ekstrak kulit buah naga memberikan pengaruh terhadap penurunan tingkat kesukaan panelis terhadap aroma mie basah. Semakin tinggi konsentrasi ekstrak kulit buah naga super merah maka tingkat kesukaan terhadap aroma mie basah akan semakin menurun. Hal ini disebabkan karena ekstrak kulit buah naga super merah memiliki aroma langu.

Hal tersebut sesuai dengan penelitian yang dilakukan Zainoldin dan Baba (2012) yang menambahkan bubur kulit buah naga pada pembuatan yogurt menunjukan bahwa terdapat permasalahan aroma langu pada buah naga merah yang disebabkan oleh aktivitas enzim lipoksigenase.

\section{Tekstur}

Berdasarkan data yang telah diperoleh, tingkat kesukaan panelis terhadap tekstur mie basah dengan penambahan ekstrak kulit buah naga super merah dapat dilihat pada Gambar 8 .

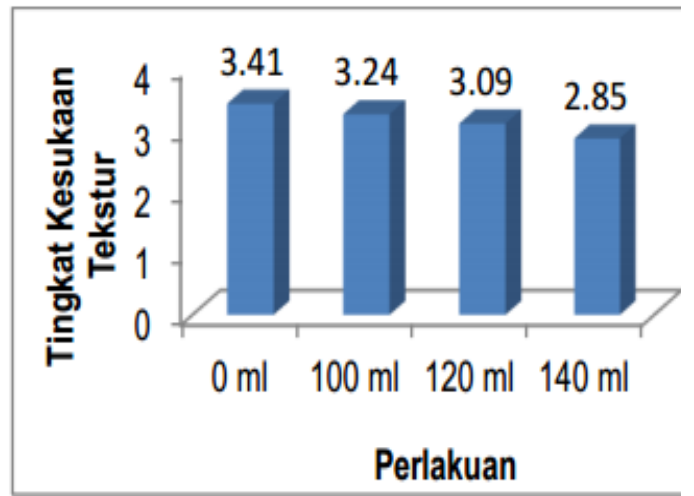

Gambar 8.

Rerata Uji Hedonik Tekstur Mie Basah Hasil analisis sidik ragam menunjukkan bahwa perlakuan penambahan ekstak kulit buah naga super merah memberikan pengaruh yang sangat nyata terhadap tekstur mie basah yang di hasilkan. Bersadarkan hasil uji lanjut Duncan, tekstur terbaik diperoleh pada perlakuan tanpa penambahan ekstrak kulit buah naga super merah

Hal ini disebabkan karena ekstrak kulit buah naga mengandung serat, dimana serat ini dapat meningkatkan daya serap air. Penyerapan air terjadi pada saat perebusan, sehingga penambahan ekstrak kulit buah naga super merah dengan konsentrasi tinggi mengakibatkan mie basah menjadi lembek dan tidak elastis. Menurut Estiasih (2006) karena kemampuannya berikatan hidrogen dengan air, polisakarida mampu menyerap air dan menahannya dalam struktur molekulnya. Pada keadaan setimbang, polisakarida dapat menahan air 8-12\%. Proses penyerapan air ini terjadi pada tahap perebusan mie basah.

\section{Kadar Air}

Berdasarkan hasil pengujian terhadap kadar air, kadar air mie basah dengan penambahan ekstrak kulit buah naga super merah dapat dilihat pada gambar 9 .

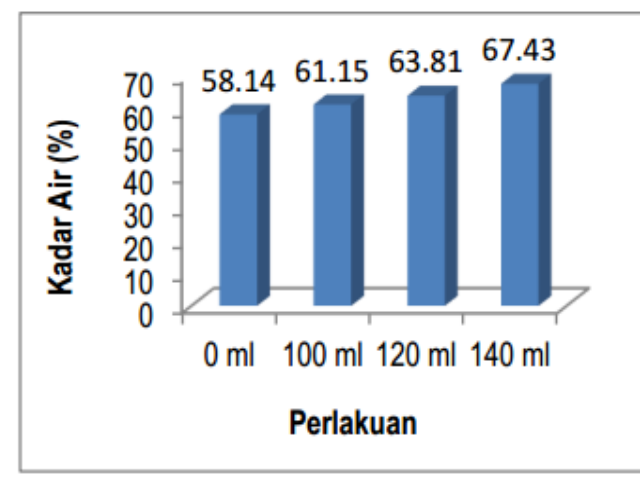

Gambar 9

Kadar air mie basah

Hasil analisis sidik ragam
terhadap kadar air mie basah menunjukkan bahwa setiap perlakuan memberikan pengaruh yang sangat nyata terhadap kadar air mie basah yang di hasilkan. Bersadarkan hasil uji lanjut Duncan, kadar air terbaik diperoleh 
pada perlakuan tanpa penambahan ekstrak kulit buah naga super merah.

Semakin banyak konsentrasi ekstrak kulit buah naga yang ditambahkan maka kadar air mie basah akan semakin meningkat. Hal ini dipengaruhi oleh kandungan serat dalam kulit buah naga super merah karena serat memiliki daya serap air yang tinggi. Hal ini sesuai dengan pendapat Tala (2009) serat pangan memiliki daya serap air yang tinggi karena ukuran polimernya besar, strukturnya kompleks, dan banyak mengandung gugus hidroksil sehingga mampu menyerap air dalam jumlah besar. Proses penyerapan air ini terjadi pada saat perebusan mie basah pada air mendidih selama 3 menit. Proses perebusan juga dapat meningkatkan kandungan air mie basah. Bahan yang mengandung pati (tepung bonggol pisang) cenderung suka air (hidrofil), karena jumlah gugus hidroksil dalam molekul pati sangat besar maka kemampuan dalam menyerap air juga besar yang menyebabkan air berada dalam butir-butir pati dan tidak dapat bergerak bebas (Safitri dan Hartini, 2012).

\section{Kadar Abu}

Berdasarkan hasil pengujian terhadap kadar abu, kadar abu mie basah dengan penambahan ekstrak kulit buah naga super merah dapat dilihat pada gambar 10.

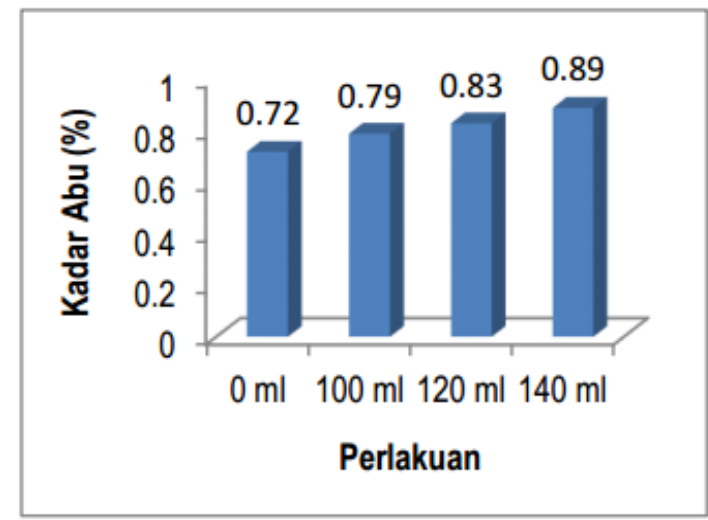

Gambar 10

Kadar abu mie basah

Hasil analisis sidik ragam menunjukkan bahwa setiap perlakuan memberikan pengaruh yang sangat nyata terhadap kadar air mie basah yang di hasilkan. Hasil analisa terhadap masing- masing kadar abu mie basah berbagai konsentrasi menyatakan telah sesuai dengan standar Nasional Indonesia No. 012987-1992 yang menyebutkan bahwa kadar abu maksimal pada mie basah yaitu $3 \%$.

Semakin tinggi konsentrasi penambahan ekstrak kulit buah naga maka akan semakin tinggi kadar abu yang dihasilkan. Hal ini disebabkan karena pada kulit buah naga mengandung mineral baik organik maupun anorganik. Menurut Jaafar,et al., (2009) Kulit buah naga mengandung vitamin $C$, vitamin $E$, vitamin $A$, alkaloid, terpenoid, flavonoid, tiamin, niasin, piridoksin, kobalamin, fenolik, karoten, dan fitoalbumin. Peningkatan kadar abu mie basah dengan penambahan ekstrak kulit buah naga ini sesuai dengan penelitian yang dilakukan oleh Wahyuni dan Nugroho (2014) yang mengatakan bahwa semakin banyak penambahan ekstrak kulit buah naga maka akan semakin bertambah kadar abu mie kering yang dihasilkan. 
Kadar Serat Kasar

Berdasarkan hasil pengujian terhadap kadar serat kasar, kadar serat kasar mie basah dengan penambahan ekstrak kulit buah naga super merah dapat dilihat pada gambar 11.

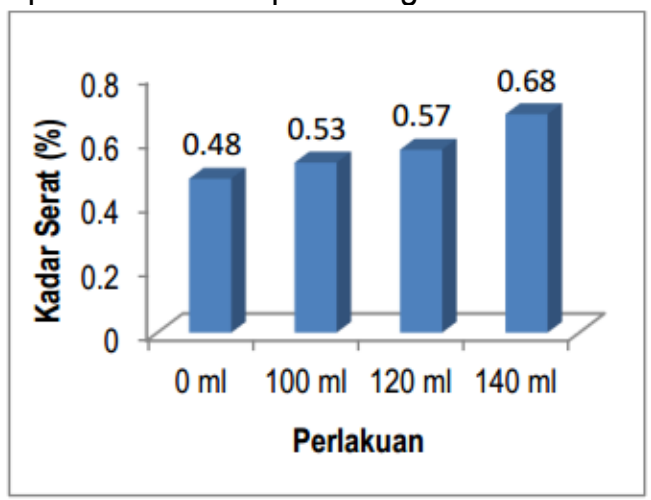

Gambar 11.

Kadar Serat Kasar Mie Basah

Hasil analisis sidik ragam menunjukkan bahwa setiap perlakuan memberikan pengaruh yang sangat nyata terhadap kadar serat kasar mie basah yang di hasilkan. Bersadarkan hasil uji lanjut Duncan, kadar serat kasar terbaik diperoleh pada perlakuan penambahan ekstrak kulit buah naga super merah $140 \mathrm{ml}$.

Terjadinya peningkatan kadar serat kasar dengan meningkatnya presentase penambahan ekstrak kulit buah naga super merah disebabkan Karena pada kulit buah naga super merah banyak mengandung serat. Hal ini sesuai dengan penelitian Waladi dan Faizah, (2015) yang mengatakan bahwa rerata kadar serat es krim semakin meningkat seiring dengan meningkatnya penambahan kulit buah naga merah. Menurut Saneto (2005) kulit buah naga merah memiliki serat sebanyak $36,2 \%$ $41.3 \%$.

\section{Kadar Antioksidan}

Berdasarkan hasil pengujian terhadap kadar antioksidan, kadar antioksidan mie basah dengan penambahan ekstrak kulit buah naga super merah dapat dilihat pada gambar 12.

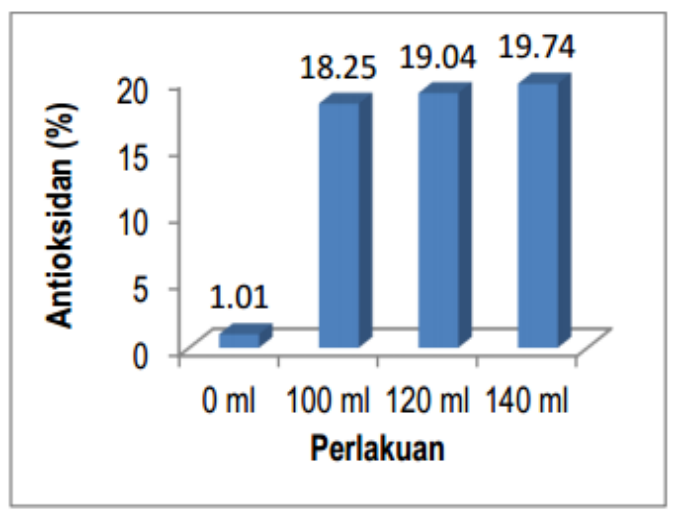

\section{Gambar 12}

Kadar Antioksidan Mie Basah

Hasil analisis sidik ragam menunjukkan bahwa setiap perlakuan memberikan pengaruh yang sangat nyata terhadap kadar antioksidan mie basah yang di hasilkan. Bersadarkan hasil uji lanjut Duncan, kadar air terbaik diperoleh pada perlakuan penambahan ekstrak kulit buah naga super merah 140 $\mathrm{ml}$.

Peningkatan kandungan antioksidan pada mie basah seiring dengan penambahan ekstrak kulit buah naga disebabkan karena kulit buah naga mengandung kadar antioksidan yang cukup tinggi. Kulit buah naga banyak mengandung antosianin yang merupakan pigmen golongan flavonoid yang larut dalam air. Kandungan antosianin diyakini dapat menghambat berbagai radikal bebas seperti radikal superoksida dan hydrogen peroksida. Antosianin dan berbagai bentuk turunannya dapat menghambat berbagai reaksi oksidasi dengan berbagai mekanisme. Menurut Meidayanti et al (2015) Kadar total antosianin pada ekstrak kulit buah naga super merah menunjukkan kadar total antosianin dengan kadar rata- rata sebesar $58,0720 \pm 0,0001 \mathrm{mg} / \mathrm{L}$ 
Antosianin diyakini mempunyai efek antioksidan yang sangat baik, hal ini sesuai dengan Sebuah penelitian yang dilakukan di Universitas Michigan Amerika menunjukkan bahwa antosianin dapat menghancurkan radikal bebas, lebih efektif daripada vitamin $\mathrm{E}$ yang selama ini telah dikenal sebagai antioksidan kuat (Winarno, 1997).

\section{KESIMPULAN}

Berdasarkan hasil pembahasan di atas, maka dapat disimpulkan sebagai berikut:

1. Hasil penelitian menunjukan bahwa substitusi tepung bonggol pisang dan tepung terigu yang terbaik adalah perlakuan A dengan $285 \mathrm{~g}$ tepung terigu : $15 \mathrm{~g}$ tepung bonggol pisang. Pada perlakuan A tingkat kesukaan panelis terhadap rasa yaitu 3.57, warna 3.69 , aroma 3.43, dan tekstur 3.61. Semakin banyak penambahan tepung bonggol pisang maka mutu dari mie basah akan semakin menurun.

2. Hasil uji panelis mie basah dengan penambahan ekstrak kulit buah naga super merah menunjukan panelis lebih menyukai rasa, aroma, dan tekstur mie basah tanpa penambahan ekstrak kulit buah naga. Sedangkan jika dilakukan penambahan ekstrak kulit buah naga panelis lebih menyukai rasa, aroma, dan tekstur mie basah dengan penambahan ekstrak kulit buah naga super merah $100 \mathrm{ml}$. Hasil uji kimia menunjukkan bahwa, perlakuan $Z$ yaitu penambahan ekstrak kulit buah naga super merah memiliki uji kimia tertinggi terdiri dari air 67.43 $\%$, abu $0.89 \%$, serat kasar $0.68 \%$ dan antioksidan $19.74 \%$.

\section{SARAN}

Berdasarkan hasil penelitian yang dilakukan, dapat dikemukakan saran sebagai berikut:

1. Sebaiknya pada pembuatan mie basah dengan substitusi tepung bonggol pisang menggunakan konsentrasi 5-10 \%. Selain itu tepung bonggol pisang lebih baik digunakan dalam membuat produk pangan yang berwarna coklat.

2. Penulis menyarankan kepada peneliti selanjutnya yang ingin melakuan penelitian mie basah dengan substitusi tepung bonggol pisang agar menggunakan bahan lain sebagai pewarna alami.

\section{DAFTAR PUSTAKA}

Badan Standardisasi Nasional. 1992. Standar Nasional Indonesia. SNI 01-2987- 1992. Mi Basah. Badan Standardisasi Nasional. Jakarta.

Ekawati Prizka, Rostiati, dan syahraeni, 2015. Aplikasi Ekstrak Kulit Buah Naga Sebagai Pewarna Alami Pada Susu Kedelai Dan Santan. Journal Agrotekbis. Fakultas Pertanian. Universitas Tadulako. Palu 3 (2) : $198-205$

Estiasih, T. 2006. Teknologi dan Aplikasi Polisakarida Dalam Pengolahan Pangan Jilid 1. Fakultas Teknologi Pertanian. Universitas Brawijaya. Malang

Estiasih, $\mathrm{T}$ dan Ahmadi, Kgs. 2011. Teknologi Pengolahan Pangan. Jakarta: Bumi Aksara

Hidayah Tri, 2013. Uji Stabilitas Pigmen Dan Antioksidan Hasil Ekstraksi Zat Warna Alami Dari Kulit Buah 
Naga (Hylocereus Undatus). Skripsi. Jurusan Kimia. Fakultas Matematika dan IImu Pengetahuan Alam. Universitas Negeri Semarang.

Jaafar, Ali, R., Nazri, M., dan Khairuddin, W., 2009, Proximate Analysis of Dragon Fruit (Hylecereus polyhizus), American Journal of Applied Sciences, 6 : 1341-1346

Juniawati. 2003. Optimasi Proses Pengolahan $\mathrm{Mi}$ Jagung Instan Berdasarkan Kajian Preferensi Konsumen. Skripsi. Departemen Teknologi Pangan dan Gizi, Fakultas Teknologi Pertanian, Institut Pertanian Bogor, Bogor.

Lensun, 2013. Pemanfaatan Sagu Baruk (Arenga Microcarpa) Dengan Ubi Jalar Ungu (Ipomoea Batatas) Dalam Pembuatan Mie Basah. Jurnal Ilmu dan Teknologi Pangan, Fakultas Pertanian, UNSRAT.

Li Chen Wu, Hsiu-Wen Hsu, Yun-Chen Chen, Chih-Chung Chiu, Yu-In Lin and Annie Ho . 2005. Antioxidant And Antiproliferative Activities of Red. Universitas Kristen Satya Wacana. Salatiga

Meidayanti Putri, Gunawan Gede, dan Suarsa Wayan, 2015. Aktivitas Antioksidan Antosianin Dalam Ekstrak Etanol Kulit Buah Naga Super Merah (Hylocereus Costaricensis) Dan Analisis Kadar Totalnya. Jurnal Kimia. Fakultas Matematika dan IImu Pengetahuan Alam. Universitas Udayana.

Permatasari, S. Widyastuti, S. dan Suciyati. 2009. Pengaruh Rasio Tepung Talas dan Tepung Terigu
Terhadap Sifat Kimia dan Organoleptik Mie Basah. Jurnal. Fakultas Pertanian. Universitas Udayana.

Rosdiana, R. 2009. Pemanfaatan Limbah dari Tanaman Pisang. Bharatara Karya Aksara, Jakarta.

Safitri dan Hartini, 2012. Substitusi Buah Sukun (Artocapus Altilis Forst) Dalam Pembuatan Mie Basah Berbahan Dasar Tepung Gaplek Berprotein. Jurnal Progdi Kimia. Fakultas Sains dan Matematika.

Saneto Budi, 2005. Karakterisasi Kulit Buah Naga Merah $(H$. Polyrhizus). Jurusan Teknologi Hasil Pertanian, Fakultas Pertanian Universitas Widyagama Malang. AGRIKA, Vol 2: 143-149.

Sediaoetama, A. D. 2006. IImu Gizi. Jakarta: Dian Rakyat.

Tala, Z. 2009. Manfaat Serat Bagi Kesehatan. Departemen IImu Gizi. Fakultas Kedokteran. Universitas Sumatera Utara

Wahyuni dan Nugroho, (2014). Pengaruh penambahan ekstrak kulit buah naga super merah terhadap produk mie kering. Jurnal Teknologi Pertanian. Fakultas Pertanian. Universitas Yudharta. Pasuruan

Waladi, V.S.J \& Faizah H. (2015). Pemanfaatan kulit buah naga merah (Hylocereus polyrhizus.) Sebagai bahan tambahan dalam pembuatan es krim. Jurnal. Fakultas Pertanian. Universitas Riau Vol 2 No. 1

Winarno, F.G., 1997. Kimia Pangan dan Gizi. Jakarta: PT. Gramedia. 
Winarno, F.G. 2002. Kimia Pangan dan

Gizi. Jakarta: PT

Gramedia Pustaka Utama.

Zainolidin, K.H. dan A.S. Baba. 2012.

The Effect of Hylocereus

polyrhizus and Hylocereus

undatus on Physicochemical,

Proteolysis and Antioxidant

Activity in Yogurt. International

Journal of Biological and Life

Sciences 8 (2) : 93-98. 